\title{
MODERN AND RAPID METHODS FOR TOXICOLOGICAL ANALYSIS OF FOODSTUFFS WITH BACTERIAL CONTAMINATION
}

\author{
Rozalina Yordanova, Katya Kichukova \\ Trakia University of Stara Zagora, \\ Medical College \\ 9 Armeiska Str., 6000 Stara Zagora, Bulgaria \\ mobile phones: $+359883335099,+359889310509$, \\ e-mail: rozalina_@abv.bg, katya_1969@abv.bg
}

\begin{abstract}
Foodborne illnesses are a widespread problem throughout the world. Food poisoning due to bacterial toxins can be caused by the ingestion of exotoxins which are preformed in the food, or by the ingestion of food containing large numbers of bacterial cells which then release endotoxins in the gastrointestinal tract. Early methods for the assay of bacteria toxins were based on in vivo or in vitro tests. Later, immunological tests were developed based on techniques such as gel diffusion. Different types of methods have been developed for the detection of toxin genes and their toxic products. These methods include the detection of toxin genes by amplification methods and hybridization probing. There are now a number of rapid test kits available which give results within hours and are much simpler to perform and interpret than bioassays.
\end{abstract}

Key words: modern and rapid methods, detection, bacterial toxins.

\section{INTRODUCTION}

Foodborne illnesses are a widespread problem throughout the world. Food poisoning due to bacterial toxins can be caused by the ingestion of exotoxins (e.g. Staphylococcus aureus enterotoxin, Bacillus cereus toxin, Clostridium botulinum toxins) which are preformed in the food, or by the ingestion of food containing large numbers of bacterial cells which then release endotoxins in the gastrointestinal tract (e.g. Clostridium perfringens food poisoning). [25]

Early methods for the assay of bacteria toxins were based on in vivo (i.e. animal challenge tests) or in vitro tests (i.e. tissue culture). Later, immunological tests were developed based on techniques such as gel diffusion, but these tests were laborious and difficult to apply to foods. There are now a number of rapid test kits available which give results within hours and are much simpler to perform and interpret than bioassays.

Different types of methods have been developed for the detection of toxin genes and their toxic products. These methods include the detection of toxin genes by amplification methods and hybridization probing. The toxins themselves have been detected using immunological assay, agglutination tests, and by bioassays.

\subsection{Biological assays}

The modern assay methods are rapid and a convenient means of testing for bacterial toxins but they do not provide information on the biological activity of the toxin. Thus, bioassays and related tests are still the method of choice for some bacterial toxins (e.g. botulinum toxins). Bioassay formats include wholeanimal tests (e.g. the mouse lethality test, monkey and kitten 


\section{ARTTE $Y^{2}$}

Ipplied Researthes in Technics, Technologies and Bduration

Journal of the Faculty of Technics and Technologies, Trakia University https://sites.google.com/a/trakia-uni.bg/artte/

emesis tests, and rabbit and guinea-pig skin tests), partanimal tests (e.g. ileal loop tests) and cell culture systems (e.g. Chinese hamster ovary $(\mathrm{CHO})$ cells).

\subsection{Immunological assays}

Immunological assays are much simpler and cheaper than biological assays. Some of the techniques for the detection of bacterial toxins and the commercial sources of kits based on these techniques are:

\subsubsection{Haemagglutination}

The methods based on haemagglutination do not require the antigen to be in a precipitable form. In the passive haemagglutination test dilutions of sample are reacted with a constant amount of antibody. When there is free antibody present, toxin coated erythrocytes which are added then, agglutinate. In the reversed passive haemagglutination test, antibody is coupled to sheep erythrocytes and agglutination occurs when toxin is present.

\subsubsection{Coagglutination}

In the coagglutination test is used to detection the toxin of Staphylococcus aureus.. A commercial version of this test for Salmonella, Shigella and enterotoxigenic E.coli is available.

\subsubsection{Reverse passive latex agglutination}

Reverse passive latex agglutination (RPLA) can be used to detect soluble antigens in food extracts or culture filtrates. The antibody is attached to latex particles and reacts with the soluble antigen (e.g. bacterial toxin). Positive reactions are indicated by the formation of a diffuse lattice pattern [8]. The assay is simple and rapid to perform, but it is relatively expensive and gives only semi-quantitative results. There are commercial tests available using RPLA for toxins including those of B.cereus, C.perfringens, B.cereus diarrhoeal toxin, Shiga toxin-producing E.coli verotoxin, S.aureus enterotoxins, and V. cholerae.

\subsubsection{Gel diffusion assays}

Gel diffusion methods include Electro-immunodiffusion, micro- Ouchterlony slide test, Oudin or single-diffusion tube test, and the microslide double diffusion test [15]. The most widely used gel diffusion test is the Crowle modification of the Ouchterlony test. Gel diffusion methods rely on diffusion of the toxin and detecting antibody in a semisolid gel (often agarose) matrix. Interaction of the toxin and antibody results in a visible precipitation band that indicating the presence of the toxin [16]. Gel diffusion assays have been used in the detection of toxins from C. botulinum, C. perfringens, and $S$. aureus enterotoxins [15].

\subsubsection{Enzyme-linked immunosorbent assay}

The quantitative enzyme-linked immunosorbent assay (ELISA) method was developed by Van Weemen and Schuurs (1971). Since then many immunoassays have been described. Most commercial kits use either limitedor excess-reagent systems with a labelled analyte or antibody in the 'sandwich' format. In the direct or double antibody sandwich ELISA, target antigen is captured by incubating the test sample in specific antibody-coated wells. The bound antigen is detected by reacting with another enzymelabelled specific antibody and an

IRTIIE Vol. 6, No. 1, 2018 ISSN 1314-8788 (print), ISSN 1314-8796 (online), doi: 10.15547/artte.2018.01.011 
enzyme-specific substrate to form a coloured or fluorescent product. The amount of label present at completion of the assay (and hence colour) is directly proportional to the target analyte concentration.

\subsubsection{Enzyme-linked immunofiltration assay}

Enzyme-linked immunofiltration assay (ELIFA) is a rapid alternative to immunoassays. There are commercially available system which has better sensitivity than the conventional ELISA. It consists of a nitrocellulose membrane placed between two chambers and connected to a peristaltic pump. Filtration of the test sample through the high affinity membrane accelerates the reaction between the analyte and the ligand immobilized on the membrane, reducing the total assay time to $1 \mathrm{~h}$, compared with $4 \mathrm{~h}$ for a typical ELISA.

\subsubsection{Radioimmunoassay}

In radioimmunoassay ( $\mathrm{RIA}$ ), a radioactive label is coupled to the antigen and the antigen is reacted with the specific antibody. The amount of antigen combined with the antibody is determined with a radioactivity counter. This technique is more sensitive than gel diffusion methods.

\subsection{Nucleic acid probes and polymerase chain reaction}

Polymerase chain reaction (PCR) was first described in the mid-1980s [20]. PCR is a highly specific and sensitive method for amplifying nucleic acids sequences exponentially. The presence or absence of a gene provides insights into the toxin-producing ability of an organism. PCR methods for toxin detection have been developed for the detection of foodborne pathogens such as Salmonella, V.cholerae, E.coli, and S.aureus.

\section{DETECTION OF BACTERIAL TOXINS}

\subsection{Staphylococcus aureus}

The ingestion of foods containing sufficient amounts of one (or more) preformed enterotoxin, produced by some strains of S.aureus leads to Staphylococcal food poisoning (SFP). 14 different staphylococcal enterotoxins have been described (designated A-O, with several gaps in the sequence). The commonest toxin type in food poisoning is type $A$.

SFP have a rapid onset $-2-8 \mathrm{~h}$. Symptoms include nausea, violent vomiting, abdominal cramping, with or without diarrhoea. The disease is usually self-limiting but can be severe enough to warrant hospitalization, when infants, elderly or debilitated people are concerned.

\subsubsection{Staphylococcal enterotoxins (SEs) identification using molecular biological methods}

- These methods usually detect genes encoding enterotoxins in strains of S.aureus isolated from contaminated foods. Polymerase chain reaction (PCR) approach is a specific, highly sensitive, rapid method that can characterize the S.aureus strains involved in SFPOs, thereby providing highly valuable information. PCR also can be combined with other techniques, such as most probable number (MPN-PCR) [22], and PCR-enzyme linked immunosorbent assay (PCR-ELISA) [14], which can provide sensitive results.

IRTIIE Vol. 6, No. 1, 2018 ISSN 1314-8788 (print), ISSN 1314-8796 (online), doi: 10.15547/artte.2018.01.011 


\section{ARTTIE $Y$}

Ipplied Resseirl ches in Technics, Technologies and Bductation

Journal of the Faculty of Technics and Technologies, Trakia University https://sites.google.com/a/trakia-uni.bg/artte/

- Multiplex PCR assays, allowing rapid and simultaneous detection of staphylococcal enterotoxigenic strains and toxin genes.

- To evaluate the toxic potential of strains isolated from SFPOs, various authors $[19,1,7]$ have recently designed primers to perform PCR and reverse transcription PCR (RT-PCR) for SE genes.

- ELISA technology - commercial kits may be in microplate or tube format and sometimes include immunoaffinity columns (IAC) for concentration of toxins from foods. ELISA kits for identification of specific SEs are available.

- Automated test based on Enzyme-Linked Fluorescence Assays (EFLA) are available.

- Biomolecular interaction analysis mass spectrometry (BIA-MS) to detection of bacterial toxins in food samples. This approach utilizes surface plasmon resonance (SPR) to detect the binding of the toxin(s) to antibodies immobilized on a surface of a sensor chip. SPR detection is then followed by identification of the bound toxin(s) by matrix-assisted laser desorption / ionization time-of-flight mass spectrometry. The method is used for identification of Staphylococcal enterotoxin B (SEB) at levels of $1 \mathrm{ng} / \mathrm{ml}$.

\subsubsection{Staphylococcal enterotoxins (SEs) identification using immunoassays}

- Optical-based immunoassays have been widely applied for SE detection in food. Opticalbased detection methods have good application prospects in biomolecular analysis. They exploit light absorption, fluorescence/luminescence, chemiluminescence, Raman scattering and refractive index for change detection. Optical-based detection methods provide fast, highly sensitive, real-time, and high-frequency monitoring which can make the detection of SEs less time-consuming, lower sample concentration, as well as easier sample pre-treatment.

- Colorimetric Immunoassays: Enzyme-linked immunosorbent assay (ELISA) is a fundamental and widely used colorimetric method.

- Fluorescent Immunoassays are the most popular approach for the detection of SEs. A variety of labels have been used in the development of SE immunoassays.

- Surface Plasmon Resonance (SPR) Immunoassays is surface-sensitive methods for SE detection. In the immunoassay, antibodies were coated onto the sensor chip and the reflection intensity changed when the target bound with the antibodies. SPR features surface-sensitive response, label-free detection, and real-time measurement capability. The presence of the analyte can be determined directly without the use of labeled molecules, which makes continuous real-time detection of biomolecular analytes possible.

\subsubsection{Immunological methods}

The most commonly used method for detecting SEs in food is based on the use of antienterotoxin polyclonal or monoclonal antibodies. Commercially available kits have been developed according to enzyme immunoassay (EIA) comprising ELISA and enzyme-linked fluorescent assay (ELFA) principles; and RPLA principles.

- The RidascreenTM SET is a sandwich ELISA for the qualitative analysis of staphylococcal enterotoxins A-E that uses monovalent antibodies. The kit was found to be highly specific, sensitive for a range of artificially contaminated food types, and relatively simple to perform, taking less than $3 \mathrm{~h}$ to complete.

- The TRANSIA immunoassay for staphylococcal enterotoxins A-E is a tube-based sandwich assay which uses a mixture of monoclonal and polyclonal antibodies. 


\section{ART'TE

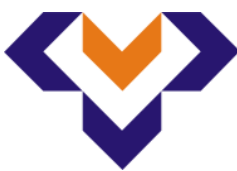 \\ Ipplied Resseirlohes in Technics, Technologies and Bductation \\ Journal of the Faculty of Technics and Technologies, Trakia University https://sites.google.com/a/trakia-uni.bg/artte/}

- The VIDAS staphylococcal enterotoxin assay is an automated enzyme-linked fluorescent immunoassay (ELFA) for the simultaneous detection of staphylococcal enterotoxins $A, B$, $C 1, C 2 C 3, D, E$ in foods. VIDAS had good sensitivity for enterotoxins $A, B, D$ and $E$, but was less sensitive for the $C$ enterotoxins.

\subsubsection{Staphylococcal enterotoxins (SEs) identification using chromatography methods}

Mass spectrometry is among the most sensitive techniques currently available because it provides specific, rapid and reliable analytical quantification of the amount of enterotoxins [5]. SEs are basic proteins that can be enzymatically degraded to peptides, which can be subsequently separated by liquid chromatography (LC), and analyzed by collision-induced dissociation tandem mass spectrometry (MS/MS), yielding information regarding the analyte based on the molecular weights or primary sequences of amino acids. LC-ESI/MS is usually used for the detection of SEs in food samples with low concentrations of soluble proteins.

\subsubsection{New Trends}

- Aptamer-Based Bioassays: Aptamers are short ssDNA or RNA molecules that were selected through in vitro selection or the systematic evolution of ligands by exponential enrichment (SELEX) [31, 9]. Aptamers bind to target molecules with similar affinity and specificity as antibodies, but they possess many competitive advantages over antibodies [23]. They can be easily produced by chemical synthesis at higher purity; have small molecular weights and superior stability that can bear repetitious denaturation and renaturation; they are an ideal recognition element for biosensors and aptamers have been alternative recognition elements applied to SEs detection.

- Molecularly Imprinted Polymers (MIPs)-Based Bioassay embody a new class of materials possessing high selectivity and affinity for the target molecules. MIPs possess molecular recognition properties due to the cavities produced in the polymer matrix that are complementary in size and shape to the target imprint molecule [26]. MIPs are stable and economical sensing. They are suitable for the substitution of natural receptors and antibodies in assays. SPR biosensor for the detection of SEB by employing MIPs as the sensing material was reported.

\subsection{Bacillus cereus}

B.cereus is a spore-forming bacterium, which can produce two different types of toxin. The commonest is the 'emetic' or vomiting toxin, a highly stable cyclic peptide also referred to as cereulide. It causes rapid onset $(0.5-6$ hours) nausea and vomiting, sometimes accompanied by diarrhoea. It is normally associated with cooked rice and is caused by preformed toxin in the food. The toxin is extremely heat-stable and will withstand cooking. The second type of B.cereus toxin is an enterotoxin. It is a protein causing a diarrhoeal type of food poisoning, which has an incubation period of 8-16 h. It is associated with a whole range of different food types, including rice, pasta, meat and meat products, and sauces.

At least two different enterotoxins have been identified, a haemolysin and a non-haemolytic enterotoxin. An intermediate type of food poisoning can occur when enterotoxin is released in the gut, but toxin can also be pre-formed in foods.

- Rapid methods for B.cereus enterotoxin have been developed based on the ELISA technique. These methods are quite sensitive and usually require only a simple extraction step.

IRTIIE Vol. 6, No. 1, 2018 ISSN 1314-8788 (print), ISSN 1314-8796 (online), doi: 10.15547/artte.2018.01.011 


\section{AR'TIE \\ ( \\ Ipplied Resseirl ches in Technics, Technologies and Bductation \\ Journal of the Faculty of Technics and Technologies, Trakia University https://sites.google.com/a/trakia-uni.bg/artte/}

- Reversed passive latex agglutination (RPLA) methods have also been developed commercially for use with food and culture filtrates. This too requires only a simple extraction procedure before use and provides a result in 24 hours.

- Lateral flow test systems uses monoclonal, rather than polyclonal antibodies for improved specificity and is said to be suitable for the rapid (time to result 4.5 hours) screening of food samples as well as for confirmation of B.cereus in culture.

- The Tecra Bacillus Diarrhoeal Enterotoxin (BDE) VIA is a microtitre plate-based immunoassay which can be used to test all types of foods and culture filtrates for BDE in $4 \mathrm{~h}$.

\subsection{Clostridium perfringens}

Clostridium perfringens food poisoning is a food-borne intoxication commonly associated with failure to refrigerate previously cooked foods. Clostridium perfringens is a spore-forming bacterium that can survive heat treatment and multiply rapidly under favourable conditions. The species is classified into five serotypes $(A-E)$ based on the major extracellular toxins produced, but only types $A$ and $C$ cause significant disease in man and type $A$ is the strain normally responsible for food-borne intoxication and infectious diarrhoea in man. The intoxication was thought to be caused by the ingestion of large numbers of vegetative cells of C.perfringens, which then sporulate in the gut and release an enterotoxin. Milligram quantities of the toxin are required to produce symptoms and the toxin is broken down in the digestive tract.

Assay for C.perfringens in foods is not carried out routinely. Most assay methods have been used to detect the toxin in faeces during the investigation of food poisoning outbreaks. Several biological methods have been described for the detection of C.perfringens enterotoxin but the need for improved speed and sensitivity has resulted in the development of immunological assays for the detection of C.perfringens enterotoxin: RPLA- and ELISAbased tests.

\subsection{Clostridium botulinum}

Botulinum neurotoxins (BoNTs) are some of the most lethal human bacterial toxins and the causative agent of botulism $[2,30]$. Botulinum food poisoning is relatively rare but is severe and has high mortality rate. Seven serotypes of BoNT $(A-G)$ have been described [4], $A, B$, $E$, and $F$ are most frequently associated with human cases of botulism $[18,3]$.

\subsubsection{ELISA and ELISA-based methods of detection}

ELISA based methods are fast, inexpensive and simple. Sharma and colleagues designed an amplified enzyme-linked immunosorbent assay (ELISA) for detecting toxins in food matrices [29]. Specifically, toxins for serotypes A, B, E, and F could be detected in liquids, solid, and semisolid food. Some of the ELISA-based methods which have been developed for examining food samples for botulinum toxins are:

- Method using digoxigen labelled IgGs and ELISA (DIG-ELISA) can be used to test food samples and/or cultures for toxin.

- A single antibody ELISA with a monoclonal capture antibody and a polyclonal antibodyenzyme conjugate to detect botulinum type $A$ toxin has been described. The assay did not appear to be affected by food constituents and no cross-reaction was observed with other botulinum toxins. 


\section{ARTTIE $Y$}

Ipplied Resseirlohes in Technics, Technologies and Bductation

Journal of the Faculty of Technics and Technologies, Trakia University https://sites.google.com/a/trakia-uni.bg/artte/

- A sandwich ELISA specific for BoNT/B that is both rapid and easy to use. This assay is based on monoclonal antibodies for both the capture and detector reagents and thus represents an assay that can be consistently produced over time without the use of animals and the variability inherent in polyclonal antisera.

- A lateral flow immunoassay able to detect and distinguish BoNT/A and BoNT/B in a few minutes [12].

\subsubsection{PCR methods}

- The GeneSystems PCR Technology have been adapted by Fach and colleagues to amplify C.botulinum genes encoding BoNT serotypes $A, B, E$, and $F$ on different microchambers [11]. This technology allows the simultaneous amplification of multiple targets along with a number of different internal controls.

- Real-time PCR methods for detection that examine expression of the NTNH (non-toxic, non-hemagglutinin) genes of clostridia have been developed, as well as methods to study toxin gene expression in C.botulinum serotypes A, B, E, and F [10].

\subsubsection{Affinity immunochromatography column-based methods}

Affinity immunochromatography column-based methods are accurate and sensitive detection of contaminated food and other biological samples. Brunt and colleagues [6] have developed a number of rapid affinity immunochromatography column (AICC) assays for the detection of BoNT serotypes $A, B, E$, and $F$ in food matrices.

\subsubsection{Immuno-polymerase chain reaction (I-PCR)}

Immuno-polymerase chain reaction (I-PCR) is an innovative approach for toxin detection combines antibodies with the amplification power of PCR in an assay called immuno-PCR (IPCR). Template DNA is conjugated to the antibody and upon binding of antigen by the antibody, an indirect test for the presence of the BoNT is carried out using PCR.

\subsection{Salmonella}

Optical biosensors have shown great potential for rapid detection of foodborne pathogens. Surface plasmon resonance (SPR) sensors have been used to detect various biological agents including Salmonella group B, D, and E, Salmonella Paratyphi [4], Listeria monocytogenes [20], Salmonella Enteritidis [3,20], Salmonella Typhimurium [3, 21], Escherichia coli O157:H7 [13].

\subsection{Enteropathogenic Escherichia coli}

The diarrhoeagenic E.coli are grouped according to their virulence factors, clinical symptoms, epidemiology and serology. The five major classes are verotoxigenic E.coli (VTEC), also known as enterohaemorrhagic E.coli (ETEC), enterotoxigenic E.coli (ETEC), enteropathogenic E.coli (EPEC), enteroinvasive E.coli (EIEC) and enteroaggregative E.coli $(\mathrm{EAggEC})$. Toxin production is only believed to be important for VTEC and ETEC.

ETEC produce two heat-stable toxins, known as STI (STa) and STII (STb), and two heatlabile enterotoxins, known as (LTI and LTII). Two related forms of STI have been described, STla (STA1 or STp) and STIb (STA2 or STh). The heat-stable toxin STI and the heat-labile toxin $\mathrm{LTI}$, which closely resembles cholera toxin, are of most significance in human disease. 


\section{ARTTE Y}

Ipplied Researirches in Technics, Technologies and Eductition

Journal of the Faculty of Technics and Technologies, Trakia University https://sites.google.com/a/trakia-uni.bg/artte/

- Assays based on immunological techniques and nucleic acid hybridization are now available. A simple gel immunodiffusion test (Biken test) has been used to detect LT producing strains of E.coli. The Biken assay is sensitive and specific but takes 3-4 days to give a result.

- The E.coli ST EIA kit (Oxoid Ltd) is a competitive enzyme immunoassay for the detection of E.coli heat stable toxins STA1 and STA2 in culture filtrates. The assay time in 3-4 h.

- The ELISA is easy to perform and gave results within $24 \mathrm{~h}$.

- Commercial agglutination kits are available for the detection of E.coli heat-labile enterotoxin (LT). The VETRPLA kit (Oxoid Ltd) and the Phadabact ETEC-LT cooagglutination test (Karo Bio Diagnostics $A B$ ) can be used to test culture filtrates and bacterial suspensions for isolation plates, respectively.

- Commercial DNA hybridization kits (ETC-01, ETC-02, ETC-03 and ETC04, Bresatec Ltd, Adelaide, Australia) are available for testing bacterial isolates for the presence of genes controlling the production of E.coli STA1, STA2, STII and LTI toxins, respectively.

VTEC, including E. coli O157: $\mathrm{H} 7$, are an important cause of human diarrhoea, haemorrhagic colitis and haemolytic uraemic syndrome in North America and Europe. VTEC produce one or more cytotoxins, known as verotoxins (VT), because of their cytotoxic effect on Vero cells [17]. VT1 has identical immunological and biological activities to Shiga toxin and is therefore also known as Shiga-like toxin (SLT). Another group of antigenically distinct toxins is known as VT2 (SLTII). Both toxins are reported to act by blocking protein synthesis [26]. The classical test for VT toxins is the Vero cell culture assay. In this test differentiation of VT1 and VT2 toxins requires neutralization of the cytotoxic activity with specific antisera.

There are several commercial immunoassays for the detection of VT in pure cultures of E.coli:

- The Verotox-F kit (Denka-Seiken) and VTEC-RPLA (Oxoid Ltd) kit can detect VT1 or VT2 in culture filtrates after an overnight incubation.

- The Verotest (Microcarb) is an ELISA that takes $3 \mathrm{~h}$ to perform and can detects, but does not differentiate, VT1 and VT2.

- The Premier EHEC (Meridian Diagnostics) is another rapid ELISA that detects VT1 and VT2 in $3 \mathrm{~h}$ and is intended for use with pure cultures or stool specimens.

- A number of nucleic acid-based assays have been described for the detection of VTEC. [30] used a pair of oligonucleotide primers, targeting conserved sequences in the VT1, VT2 and VTE genes, to develop a PCR assay for all types of VTEC. PCR method might be suitable for screening E.coli isolates from foods and faeces for VT production.

\section{FUTURE TRENDS}

The modern food industry is an increasingly complex business, meeting consumer demand for a wide range of food types, from minimally processed to modified-atmospherepackaged products. Commercial, legislative and hygiene concerns and other pressures, together with the move toward hazard analysis and on-line monitoring systems, will no doubt ensure that the sensitivity and specificity of techniques for bacterial toxins will continue to improve.

Cultural enrichment methods for detection of bacterial toxins are most widely used, but timeconsuming and therefore inadequate for rapid pathogen detection from food samples. Modern and rapid detection of bacterial pathogens and toxins in foods provides real-time results to mitigate foodborne illness outbreaks and ensures public health safety and security. New technologies for detection of bacterial toxins in food such as immunosensors combined with optical, electrical and mass transducer detection techniques, are reliable options. The bioassays based on an aptamers, peptides, and other have superior characteristics of sensitivity, selectivity, rapidity and reliability.

IRTIIE Vol. 6, No. 1, 2018 ISSN 1314-8788 (print), ISSN 1314-8796 (online), doi: 10.15547/artte.2018.01.011 

https://sites.google.com/a/trakia-uni.bg/artte/

\section{REFERENCES}

[1] Akineden Ö., Hassan A.A., Schnieder E., Usleber E. (2008): Enterotoxinogenic properties of $S$. aureus isolated from goats' milk cheese. International Journal of Food Microbiology, 124: 211-216.

[2] Arnon SS, Schechter R, Inglesby TV, Henderson DA, Bartlett JG, Ascher MS, Eitzen E, Fine AD, Hauer J, Layton M, Lillibridge S, Osterholm MT, O'Toole T, Parker G, Perl TM, Russell PK, Swerdlow DL, Tonat K; Working Group on Civilian Biodefense. Botulinum toxin as a biological weapon: medical and public health management. Author information Erratum in JAMA 2001 Apr 25;285(16):2081.

[3] Betty GM, Gortemaker J, Goverde RLJ, Knapen F, Bergwerff AA. Surface plasmon resonance (BIACORE) detection of serum antibodies against Salmonella enteritidis and Salmonella typhimurium. Journal of Immunological Methods. 266: 33-44 (2002).

[4] Bokken GCAM, Corbee RJ, Knapen F and Bergwerff AA 2003 Immunochemical detection of Salmonella group B, D and E using an optical surface plasmon resonance biosensor FEMS Microbiology Letters 222 75-82.

[5] Virginie BRUN, Alain DUPUIS, Annie ADRAIT, Marlène MARCELLIN, Damien THOMAS, Magali COURT, François VANDENESCH and Jérôme GARIN. IsotopeLabeled Protein Standards: Towards Absolute Quantitative Proteomics MCP Papers in Press. Published on September 11, 2007 as Manuscript M700163-MCP200.

[6] Brunt, J., Webb, M. D., and Peck, M. W. (2010). Rapid affinity immunochromatography column-based tests for sensitive detection of Clostridium botulinum neurotoxins and Escherichia coli O157. Appl Environ Microbiol 76(13), 4143-50.

[7] 7.Derzelle S, Dilasser F, Duquenne M \& Deperrois V (2009) Differential temporal expression of the staphylococcal enterotoxins genes during cell growth. Food Microbiol 26: 896-904.

[8] Doyle, M. P., Beuchat, L. R., and Montville, T.J. (2001) Food Microbiology Fundamentals and Frontiers, ASM Press, Washington, DC, pp. 171-91.

[9] Ellington, A.D.; Szostak, J.W. In vitro selection of RNA molecules that bind specific ligands. Nature 1990, 346, 818-822.

[10] Fach, P., Micheau, P., Mazuet, C., Perelle, S., and Popoff, M. (2009). Development of real-time PCR tests for detecting botulinum neurotoxins A, B, E, F producing Clostridium botulinum, Clostridium baratii and Clostridium butyricum. J Appl Microbiol 107(2), 46573.

[11] Fach, P., Fenicia, L., Knutsson, R., Wielinga, P. R., Anniballi, F., Delibato, E., Auricchio, B., Woudstra, C., Agren, J., Segerman, B., de Medici, D., and van Rotterdam, B. J. (2011). An innovative molecular detection tool for tracking and tracing Clostridium botulinum types A, B, E, F and other botulinum neurotoxin producing Clostridia based on the GeneDisc cycler. Int J Food Microbiol 145 Suppl 1, S145-51.

[12] Ferreira, J.L. Comparison of amplified ELISA and mouse bioassay procedures for determination of botulinum toxins A, B, E, and F. J. AOAC Int. 2001, 84, 85-88.

[13] Fratamico PM, Strobaugh TP, Medina MB, Gehring AG. Detection of Escherichia coli $\mathrm{O} 157: \mathrm{H7}$ using a surface plasmon resonance biosensor. Biotechnology Techniques. 12: 571- 576 (1998).

[14] Gilligan, K.; Shipley, M.; Stiles, B.; Hadfield, T.; Ibrahim, M.S. Identification of Staphylococcus aureus enterotoxins A and B genes by PCR-ELISA. Mol. Cell. Probes 2000, 14, 71-78.

[15] Jay, J. M. (2000) Modern Food Microbiology (6 $6^{\text {th }}$ ed.), Gaithersburg, MD: Aspen, 531.

[16] Klein, J. and Horejsi, V. (1997) Immunology, $2^{\text {nd }}$ ed. Blackwell Scienthific Publishers, Oxford. 


\section{ARTTIE $Y$}

Ipplied Resseirlohes in Technics, Technologies and Bductation

Journal of the Faculty of Technics and Technologies, Trakia University https://sites.google.com/a/trakia-uni.bg/artte/

[17] Konolwalchuk, J., Speirs, J.I. and Stavic, S. (1977) Vero response to a cytotoxin of Escherichia coli. Infection and Immunity 18, 775-779.

[18] Koubova V, Brynda E, Karasova L, Skvor J, Homola J, Dostalek J, Tobiska P, Rosicky J. Detection of foodborne pathogens using surface plasmon resonance biosensors. Sensors and Actuators B. 74: 100-105 (2001).

[19] Lee YD, Moon BY, Park JH, Chang HI \& Kim WJ (2007) Expression of enterotoxin genes in Staphylococcus aureus isolates based on mRNA analysis. J Microbiol Biotechnol 17: 461-467.

[20] Mäntynen, V.; Niemelä, S.; Kaijalainen, S.; Pirhonen, T.; Lindström, K. MPN-PCRQuantification method for Staphylococcal enterotoxin C 1 gene from fresh cheese. Int. J. Food Microbiol. 1997, 36, 135-143.

[21] Medina MB. Binding interaction studies of the immobilized Salmonella typhimurium with extracellular matrix and muscle proteins, and polysaccharides. International Journal of Food Microbiology. 93: 63-72 (2004).

[22] Mullis, K., Faloona, S., Scharf, S., Saiki, R., Horn, G. and Erlich, H. (1986) Specific enzymic amplification of DNA in vitro: the polymerase chain reaction. Cold Spring Harbor Symp Quant Biology 51, 263-273.

[23] Nimjee, S.M.; Rusconi, C.P.; Sullenger, B.A. Aptamers: An emerging class of therapeutics. Annu. Rev. Med. 2005, 56, 555-583.

[24] Ogasawara, T., Ito, K., Igarashi, K., Yutsudo, T. and Takeda, Y. (1988) Inhibition of protein synthesis by a Vero toxin (VT2 of Shiga-like toxin II) produced by Escherichia coli 0157:H7 at the level of elongation factor 1-dependent aminoacyl-tRNA binding to ribosomes. Microbial Pathology 4, 127-135.

[25] Oh BK, Lee W, Kim YK, Lee WH, Choi JW. Surface plasmon resonance immunosensor using self-assembled protein $G$ for the detection of Salmonella paratyphi. Journal of Biotechnology. 111: 1-8 (2004).

[26] Piletsky, S.A.; Piletska, E.V.; Bossi, A.; Karim, K.; Lowe, P.; Turner, A.P. Substitution of antibodies and receptors with molecularly imprinted polymers in enzyme-linked and fluorescent assays. Biosens. Bioelectron. 2001, 16, 701-707.

[27] Pimbley D.W, Patel P.D. (1998) A review of analytical methods for the detection of bacterial toxins. Journal of Applied Microbiology - Symposium Supplement, 84, 98S1095 .

[28] Read, S.C., Clarke, R.C., Martin, A. et al. (1992) Polymerase chain reaction for detection of verotoxigenic Escherichia coli isolated from animal and food sources. Molecular Cell Probes 6, 153-161.

[29] Sharma, S. K., Ferreira, J. L., Eblen, B. S., and Whiting, R. C. (2006). Detection of type $A, B, E$, and $F$ Clostridium botulinum neurotoxins in foods by using an amplified enzymelinked immunosorbent assay with digoxigenin-labeled antibodies. Appl Environ Microbiol 72 (2), 1231-8.

[30] Simpson, L.L. Identification of the major steps in botulinum toxin action. Annu. Rev. Pharmacol. Toxicol. 2004, 44, 167-193.

[31] Tuerk, C.; Gold, L. Systematic evolution of ligands by exponential enrichment: RNA ligands to bacteriophage T4 DNA polymerase. Science 1990, 249, 505-510. 